УДК 681.513:62-58, DOI 10.31210/visnyk2018.02.25

(C)2018

Лсві Л. І., доктор технічних наук, професор

Полтавський національний технічний університет імені Юрія Кондратюка

\title{
ВИКОРИСТАННЯ НЕЧІТКОЇ ЛОГІКИ ДЛЯ АВТОМАТИЗАЦІЇ ФУНКЦІОНУВАННЯ ЗРОШУВАЛЬНИХ СИСТЕМ
}

\author{
Рецензент - доктор технічних наук О. В. Шульга
}

Розглянуто підхід до автоматизаиії проичесу керування зрошувальними системами із застосуванням нечіткої логіки. Потужність та інтуїтивна простота нечіткої логіки як методології вирішення проблем гарантує ї̈ успішне застосування в системах контролю та аналізу інформації. При ичьому відбувається підключення людської інтуїиї та досвіду оператора. Запропонований підхід дозволяє підвищити точність керування вологістю трунту, забезпечити отримання планових врожаїв сільськогосподарських культур, економити водні та енергетичні ресурси за рахунок їх раціонального використання.

Ключові слова: автоматизоване керування зрошувальними системами, нечітка логіка, удосконалення стратегій керування $i$ координації дій, самоадаптивний метод, системи автоматизованого керування вологозабезпеченістю сільськогосподарських культур при підгрунтовому зволоженні з врахуванням діючих збурень.

Постановка проблеми. Перетворення сільськогосподарського виробництва на високорозвинутий сектор економіки неможливе без зменшення його залежності від несприятливих природокліматичних умов шляхом ведення зрошуваного землеробства у зонах недостатнього та нестійкого зволоження. Зрошуване землеробство $\epsilon$ важливою складовою виробництва продукції рослинництва, стабілізуючим фактором продовольчого та ресурсного забезпечення держави, особливо в роки 3 несприятливими погодними умовами. В залежності від кліматичних умов, рельєфу, глибини залягання грунтових вод застосовують різні види зрошення: краплинне, дощування, полив по смугам і борознам та підгрунтове. На територіях із надмірним зволоженням для зменшення вологості грунту до необхідного для сільськогосподарських культур рівня застосовують осушувальні системи. На територіях $з$ глибиною залягання грунтових вод до 2 м та рівнинним рельєфом широко застосовують підгрунтове зволоження. Прикладами є західна та центральна частини України, Білорусь. Крім того, через незадовільний технічний стан меліоративної мережі в посушливі роки не на всій площі використовуються за призначенням сис- теми двобічної дії. Існує потреба відновлення ефективного функціонування наявних меліоративних систем на осушуваних землях, що не повною мірою забезпечується шляхом використання ручного режиму регулювання вологості грунту. Існуючі засоби водорегулювання потребують вдосконалення у напрямку покращення точності регулювання рівнів води, врахування впливу випадкових зовнішніх збурень, забезпечення ресурсозберігаючих режимів зрошення сільськогосподарських рослин в умовах дефіциту водних та енергетичних ресурсів, що створить умови для ефективного ведення землеробства.

Аналіз останніх досліджень і публікацій, у яких започатковано розв'язання проблеми. Найбільша врожайність сільськогосподарських культур досягається при оптимальній кількості вологи, живлення, тепла, повітря і світла. При цьому необхідний для сільськогосподарських культур водний режим грунту створюється відповідним режимом зрошення, який встановлює норми, терміни і кількості поливів в залежності від біологічних особливостей культур, природних і господарських умов. При визначенні витрат води на зрошення враховують водоспоживання або сумарне випаровування, що залежить від кліматичних умов, кількості теплової енергії, яка надходить на поверхню, вологості грунту, виду та врожайності культури.

Питання управління водогосподарськомеліоративними об“єктами у зоні надлишкового та нестійкого зволоження України на рівнях стратегічного та тактичного планування на основі поєднання короткотермінового та довготермінового метеорологічних прогнозів розглянуто у [3]. У [5] розроблено метод управління вологістю грунту на основі багатошарової моделі вологопереносу. Однак залишаються відкритими питання адаптації і самонавчання автоматизованих систем керування вологістю грунту в умовах дії випадкових погодних факторів, зміни характеристик об“єкта керування, підвищення точності керування завдяки оперативному врахуванню дії збурень на об‘єкт, забезпечення отримання планової врожайності сільськогосподарських 


\section{TEХНІЧНІ НАУКИ}

культур при раціональному використанні енергетичних і водних ресурсів. Крім того, сучасні системи керування вологозабезпеченістю сільськогосподарських культур повинні не тільки забезпечувати достатню точність керування, а й прогнозувати потребу рослин у воді на певний період, мінімізувати енергетичні та водні витрати без втрати врожаю, бути надійними та зручними в експлуатації, надавати оператору повну та своєчасну інформацію про значення усіх параметрів та стан системи керування. Комплексне вирішення цих проблем можливе лише за допомогою розробки сучасних технічних засобів автоматизації, нових математичних моделей вологопереносу у ненасиченій зоні грунту та методів керування вологозабезпеченістю сільськогосподарських культур. Таким чином, розробка методів автоматизованого керування вологозабезпеченістю сільськогосподарських культур з врахуванням збурень $\epsilon$ актуальним науковопрактичним завданням.

Мета і задачі дослідження. Метою роботи $є$ побудова моделей і пошук методів керування вологозабезпеченістю сільськогосподарських культур 3 підгрунтовим зволоженням для підвищення ефективності функціонування цих систем та забезпечення отримання гарантованих врожаїв сільськогосподарських культур 3 одночасною економією водних та енергетичних ресурсів. Для досягнення поставленої мети необхідно вирішити наступні задачі:

1. Аналіз існуючих методів керування вологозабезпеченістю сільськогосподарських культур, математичних моделей вологопереносу.

2. Розробка прогнозуючих математичних моделей вологопереносу в ненасиченій зоні модульної ділянки грунту на основі нейронних мереж.

3. Розробка методів керування вологозабезпеченістю сільськогосподарських культур при підгрунтовому зволоженні 3 врахуванням дії збурень на основі нечіткої логіки.

Об‘єктом дослідження є процеси автоматизованого керування вологозабезпеченістю сільськогосподарських культур з підгрунтовим зволоженням.

Предметом дослідження є математичні моделі, методи та системи автоматизованого керування вологозабезпеченістю сільськогосподарських культур при підгрунтовому зволоженні 3 врахуванням діючих збурень.

Методи дослідження включають моделі та методи нечіткої логіки та адаптивного керування складними технічними системами в умовах невизначеності.
Результати дослідження. Для формалізації невизначеностей в задачах автоматичного управління використовуються такі методи, як імовірнісний (стохастичний) підхід, нечітка логіка (fuzzy logic), хаотичні системи. Вперше термін нечітка логіка (fuzzy logic) був введений американським професором Лотфі Заде у 1965 році в роботі «Нечіткі множини» в журналі «Інформатика та керування». Областю впровадження методів нечіткої логіки являються різні системи керування, у тому числі такі: нелінійний контроль за процесами (виробництво); системи, що самонавчаються (класифікатори); дослідження ризикових та критичних ситуацій; розпізнавання образів; фінансовий аналіз (ринки цінних паперів); дослідження даних (корпоративні сховища); удосконалення стратегій керування і координації дій, наприклад складне промислове підприємство [1, 2, 6-8, 10$]$.

Потужність та інтуїтивна простота нечіткої логіки як методології вирішення проблем гарантує їі успішне застосування у вбудованих системах контролю та аналізу інформації. При цьому відбувається підключення людської інтуїції та досвіду оператора $[4,7,11,12]$. На відміну від традиційної математики, яка потребує на кожному кроці моделювання точних і однозначних формулювань закономірностей, нечітка логіка пропонує цілком інший рівень мислення, завдяки якому творчий процес моделювання відбувається на найвищому рівні абстракції, при якому використовується лише мінімальний набір закономірностей. Нечіткі числа, які отримуються в результаті «не повністю точних вимірювань», багато в чому аналогічні розподілам теорії ймовірностей, але вільні від притаманним останнім недоліків:

- мала кількість придатних до аналізу функцій розподілу,

- необхідність їх примусової нормалізації, дотримання вимог адитивності,

- труднощі обгрунтування адекватності математичної абстракції для опису поведінки фактичних величин.

При зростанні точності нечітка логіка приходить до стандартної булевої. У порівнянні з імовірнісним методом, нечіткий метод дозволяє суттєво скоротити об'єм необхідних обчислень, що, у свою чергу, призводить до підвищення швидкодії нечітких систем $[8,12,14]$. Недоліками нечітких систем є такі:

- відсутність стандартної методики конструювання нечітких систем;

- неможливість математичного аналізу нечітких систем існуючими методами; 


\section{TЕХНІЧНІ НАУКИ}

- застосування нечіткого підходу у порівнянні із імовірнісним не призводить до підвищення точності обчислень.

Розглянемо конкретні приклади. Більшість засобів для прогнозування паводків в Індії базуються на статистичних методах [16]. Для деяких пілотних проектів використовуються мережеві або багатопараметричні гідрологічні моделі. Традиційні системи комунікації зазвичай використовуються для передачі даних у реальному часі. Автоматичні системи комунікації, наприклад, системи телеметрії, зазвичай використовуються у пілотних проектах або в обмежених масштабах. У посушливих i напівпосушливих територіях трапляються стрімкі повені. Система для прогнозування повенів відсутня. В результаті виникають людські жертви і втрати майна. Тому є необхідність у значному покращенні прогнозування повенів у реальному часі.

Ефективні автоматичні комунікаційні системи необхідні для передачі даних у реальному часі. Засоби прогнозування, такі як детерміністичні і стохастичні моделі та нечітка логіка, потребують навчання. Відповідний метод може бути рекомендований для широкого застосування і базується на виконанні оціночного критерію i розглядає корисність даних та мету прогнозу. Інформація про повінь повинна своєчасно поширюватися серед населення так, щоб план евакуації можна було вчасно спланувати і реалізувати. Гідрологічну інформаційну систему планується розробити для усіх річок Індії [16]. Виникнення повенів та їх прогнозування залежить від роботи природної дренажної системи річки. Цей процес є комплексним і його відображення у відповідну модель для автоматичного прогнозування повенів, відповідно, є складним.

Гідрологічні моделі корисні тому, що представляють процеси у світі. Математичні моделі, розроблені на базі фізичного або статистичного аналізу для оцінки повенів від малих до великомасштабних водозборів, вимагають точних знань про усі вхідні змінні. Нечітка логіка пропонує більш гнучкий, менш залежний від припущень та самоадаптивний метод для моделювання процесів виникнення повенів, які за своєю природою є складними, нелінійними та динамічними. Моделі на базі нечіткої логіки можуть використовуватися для моделювання процесів 3 неповною вхідною інформацією. Нечітка логіка високо цінується як ефективний метод роботи з нелінійностями, які присутні у гідрологічних процеcax [16].

Даний підхід може використовуватися для моделювання систем у реальному часі [16]. До інших переваг нечіткої логіки належать можливість швидко розробляти моделі, менший час моделювання i, як наслідок, нижча ціна, можливість інтегрувати нечітку логіку у традиційні моделі, здатність надавати засоби для прогнозування. Процедури нечіткої логіки використовуються, коли традиційні процедури $є$ досить складними або дорогими, у модельованому процесі присутня нечітка, змінна у часі інформація. У нечіткій логіці можна описувати наявні знання безпосередньо у лінгвістичні формі відповідно до правил.

Кількісна та якісна властивості можуть бути поєднані у нечіткій моделі. Внаслідок цього процес моделювання стає простішим, легше керованим і наближеним до людського мислення у порівнянні із традиційними методами. Використання нечіткої логіки для процесів прогнозування в гідрології $є$ відносно новою областю для досліджень і потенціалом для покращення прогнозування повенів шляхом поєднання інших технологій м'яких обчислень у гібридні рішення.

Нещодавно теорія нечіткої логіки була представлена щоб пов“язати між собою змінні у розрахунках гідрологічних процесів і моделювання поведінки агрегатів. В подальшому концепція прийняття рішень на основі нечіткої логіки, нечітке математичне програмування мають великий потенціал у моделях прогнозування повенів для прийняття вагомих рішень в умовах невизначеності [16]. Нечітка логіка застосовується у геології для представлення величин у вигляді нечітких множин, визначення різних геологічних характеристик (пористості, швидкості росту коралів, рівня осадочних утворень, проникності грунту), у геотехнічній інженеріі, поверхневій i підгрунтовій гідрології, дослідженні гідрокарбонатних порід, оцінці грунтових вод, дослідженні процесів виникнення землетрусів, грунтів та геоморфології, зміщення осадочних порід; у гідрокліматичному моделюванні (довготермінове статистичне прогнозування засух у Небрасці (США) та Угорщині, довготермінове статистичне прогнозування опадів в Угорщині, Аризоні (США) та Німеччині) [9]; дослідження відкладень вапняку, осадочних порід, наносів піску, зміни рівня моря, границь континентів, морфології каналів, річкових наносів [15].

Нечітка логіка у гідрології застосовується для моделювання та представлення величин, наприклад, метеопараметрів (температура, вологість, опади, атмосферний тиск), евапорації, температури води, інфільтрації, поверхневого стоку у вигляді нечітких множин; класифікації клімату, водоносних горизонтів, оцінки величини соняч- 


\section{ТЕХНІЧНІ НАУКИ}

ної радіації, водного балансу, прогнозування та моделювання рівня води в озерах.

Проводилося також моделювання інтенсивності руху транспорту по річках; прогнозування споживання питної води людиною в залежності від іiі ваги, рівня фізичної активності та температури повітря, споживання питної води конкретними містами (Туреччина) [13].

Отже, за своїми властивостями методи нечіткої логіки придатні також і для моделювання складних, нелінійних процесів вологопереносу в грунтах.

Висновок. Розв“язання задач розробки про-

\section{БІБЛІОГРАФІЯ}

1. Борисов В. В. Нечёткие модели и сети / В.В. Борисов, В.В. Круглов, А.С. Федулов. - М. : Горячая линия - Телеком, 2007. - 284 с.

2. Дорф $Р$. Современные системы управления / Р. Дорф, Р. Бишоп; Пер. с англ. Б.И. Копылова. - М. : Лаборатория Базовых знаний, 2004. - 832 с.

3. Науково-методичні та організаційні засади управління водогосподарсько-меліоративними об‘єктами гумідної зони України за короткотерміновим метеорологічним прогнозом. Методичні рекомендації. / А.М. Рокочинський, Я.Я. Зубик, Л.В. Зубик, С.І. Покладньов; за участю спеціалістів Держводгоспу України В.А. Сташук, В.Д. Крученюк. - Рівне : НУВГП, 2005. - 53 с.

4. Рутковская Д. Нейронные сети, генетические алгоритмы и нечёткие системы / Д. Рутковская, М. Пилиньский, Л. Рутковский: Пер. с польского И.Д. Рудинского. - М. : Горячая линия - Телеком, 2007. - 452 с.

5. Скрипник О. В. Системы двустороннего регулирования водного режима / О.В. Скрипник // Гидротехника и мелиорация. - 1984. - №4. - С. 55-57.

6. Усков A. A. Интеллектуальные технологии управления. Искусственные нейронные сети и нечёткая логика / А.А. Усков, А.В. Кузьмин М.: Горячая линия - Телеком, 2004. - 143 с.

7. Bojadziev G. Fuzzy Logic for Business, Finance and Management / George Bojadziev, Maria Bojadziev. - New Jersey: World Scientific Publishing Co., 2007. - 232 p.

8. Chen, G. (Guanrong) Introduction to fuzzy sets, fuzzy logic, and fuzzy control systems / Guan- гнозуючих математичних моделей вологопереносу, методів керування вологозабезпеченістю сільськогосподарських культур 3 оперативним врахуванням дії збурень, забезпеченням економії водних та енергетичних ресурсів, удосконалення структури гідравлічних регуляторів вологості, комплексної автоматизації зрошувальних систем iз включенням усіх елементів у єдину інформаційну систему може бути досягнуто за допомогою застосування методів інтелектуального керування і моделювання на базі нечіткої логіки, впровадження сучасних технічних засобів автоматизації та інформаційних технологій.

rong Chen, Trung Tat Pham. - Boca Raton, London, New York: CRC Press LLC, 2001. - 316 p. 99

9. Demicco, Robert $V$. Fuzzy Logic in Geology / Robert V. Demicco, George J. Klir. - Amsterdam: Elsevier Academic Press, 2004. - 347 p.

10. Espinosa J. Fuzzy Logic, Identification and Predictive Control / Jairo Espinosa, Joos Vandewalle, Vincent Wertz. - USA: Springer-Verlag London Limited, 2005. - 263 p.

11. Kecman Vojislav. Learning and Soft Computing. Support Vector Machines, Neural Networks, and Fuzzy Logic Models / Vojislav Kecman. - Massachusetts: Massachusetts Institute of Technology, 2001. $-541 \mathrm{p}$.

12. Ross, Timothy J. Fuzzy Logic with Engineering Applications / Timothy J. Ross. - England: John Wiley \& Sons Ltd., 2004. - 628 p.

13. Sen Zekai Fuzzy logic and hydrological modeling / Zekai Sen. - Boca Raton, London, New York: CRC Press, Taylor and Francis Group, 2010. $-340 \mathrm{p}$.

14. Sivanandam S.N. Introduction to Fuzzy Logic using Matlab / S.N. Sivanandam, S. Sumathi, S.N. Deepa. - Berlin: Springer-Verlag Berlin Heidelberg, 2007. $-430 \mathrm{p}$.

15. Wang, Paul P. Studies in Fuzziness and Soft Computing. Fuzzy Logic: A Spectrum of Theoretical and Practical Issues / Paul P. Wang, Da Ruan, Etienne E. Kerre. - Berlin: Springer-Verlag Berlin Heidelberg, 2007. - 459 p.

16. Wheater Howard Hydrological modeling in arid and semi-arid areas / Howard Wheater, Soroosh Sorooshian, K.D. Sharma. - New York: Cambridge University Press, 2008. - 223 p. 


\section{ANNOTATION}

Levy L. I. The use of fuzzy logic for the automation of the operation of irrigation systems.

The highest yield of agricultural crops is achieved with the optimal amount of moisture, nutrition, heat, air and light. In this case, the necessary water regime for agricultural crops is created by the appropriate irrigation regime, which establishes the norms, timing and number of irrigation, depending on the biological characteristics of crops, natural and economic conditions. In determining the flow of water to irrigation take into account water consumption or total evaporation, which depends on climatic conditions, the amount of thermal energy that enters the surface, soil moisture, species and yield of the crop.

Therefore, the issues of adaptation and selfstudying of automated systems for controlling soil moisture in the conditions of the action of random weather factors, changes in the characteristics of the control object, improving the accuracy of control due to the operational consideration of the perturbations of the object, ensuring the receipt of planned yields of agricultural crops for the rational use of energy and water resources. In addition, modern water management systems for crops should not only provide sufficient management accuracy, but also forecast the need for plants in water for a certain period, minimize energy and water costs without loss of crop, be reliable and easy to operate, provide the operator with complete and timely
\end{abstract}

information the value of all parameters and the state of the control system. A comprehensive solution to these problems is possible only through the development of modern technical means of automation, new mathematical models of moisture transfer in the unsaturated zone of soil and methods of managing moisture content of agricultural crops. Thus, the development of methods for automated management of moisture content of agricultural crops, taking into account perturbations, is an actual scientific and practical task.

To solve these problems, the approach to automating the management of irrigation systems with the use of fuzzy logic is considered. The power and intuitive simplicity of fuzzy logic as a solution to problems ensures its successful application in information monitoring and analysis systems. At the same time there is a connection of human intuition and operator experience. The offered approach allows to improve the accuracy of soil moisture management, to ensure that planned crops are harvested, and to save water and energy resources at the expense of their rational use.

Key words: automated management of irrigation systems, fuzzy logic, improvement of control strategies and coordination of actions, self-adaptive method, systems of automated control of moisture supply of agricultural crops under subsoil humidification, taking into account existing perturbations. 